\title{
DETEKSI DINI DERAJAT KESADARAN MENGGUNAKAN PENGUKURAN NILAI KRITIS MEAN ARTERY PRESSURE
}

\author{
(Detection of the Degree of Awareness Using the Measurement of \\ Critical Value Mean Artery Pressure on Nursing Care)
}

\author{
Martono*, Sudiro*, Satino* \\ *Keperawatan Politeknik Kesehatan Surakarta \\ J1. Letjend Sutoyo Mojosongo Surakarta, 0271-856929. Fax. 0271-855388 \\ Email: must_ton@ymail.com
}

\begin{abstract}
ABSTRAK
Pendahuluan: Dampak Trauma cranio cerebral dapat mempengaruhi gangguan autoregulasi volume intrakranial yang terdiri dari otak, cairan serebrospinal dan darah dalam pembuluh darah. Perubahan salah satu volume tersebut tanpa diikuti respon kompensasi dari faktor yang lain akan menimbulkan perubahan tekanan intrakranial dan jumlah aliran darah dari sirkulasi sistemik yang diperlukan untuk memberi oksigen dan glukosa yang adekuat untuk metabolisme otak. Salah satu hal yang sangat penting dalam asuhan keperawatan pada pasien dengan cidera kepala adalah menjaga kecukupan Mean Arteri Pressure serebral. Penelitian ini bertujuan untuk mengetahui kecukupan nilai kritis mean artery pressure dalam mendeteksi tingkat kesadaran pada pasien yang mengalami cidera kepala. Metode: Penelitian ini menggunakan disain explanatory research dengan pendekatan cross sectional yang menjelaskan pengaruh dan prediksi kecukupan nilai kritis mean arteria pressure terhadap derajat kesadaran pada pasien cidera kepala yang berjumlah 34 sampel. Uji statistik penelitian ini menggunakan regresi sederhana. Hasil: Hasil penelitian menunjukkan bahwa ada pengaruh yang positif nilai kritis mean artery pressure terhadap derajat kesadaran yang ditunjukkan nilai $\mathrm{p}=0.00<0.05$ dan nilai mean artery pressure mampu mendeteksi tingkat kesadaran pasien cidera kepala sebesar 77.8\%. Diskusi: Peningkatan nilai kritis Mean Arterial Pressure lebih dari $65 \mathrm{mmHg}$ dapat memperbaiki mikrosirkulasi dan autoreglasi otak, sehingga mencegah terjadinya penurunan kesadaran pada pasien cidera kepala.
\end{abstract}

Kata kunci: mean artery pressure (MAP), kesadaran, cidera kepala

\begin{abstract}
Introduction: The Impact of the trauma cranio cerebral can affect the volume autoregulation disorders any intracranial disease that consists of the brain and cerebrospinal fluid and the blood in the veins. The changes one of the volume without followed the response of compensation from the other factors will cause overt increased intracranial pressure changes and the amount of blood flow from the systemic circulation required to give oxygen and glucose intake to the metabolism of the brain. One of the things that is very important in nursing nursery on patients with injury head is to maintain the adequacy of Mean Artery Pressure cerebral. This research aims to know the adequacy of critical value mean artery pressure in detecting the level of consciousness in patients who suffered injury on the head. Method: This research using explanatory design research with cross sectional approach that explains the influence and the prediction of the adequacy of the critical value mean arteria pressure against the degree of awareness in patients with injury head which numbered 34 samples. This research statistics tests using simple regression. Result: The results of the study showed that there is a positive influence critical value mean artery pressure against the degree of awareness that indicated the value of $p=0.00<0.05$ and value of mean artery pressure is able to detect the level of consciousness patients injury head of $77.8 \%$. Discussion: Increased critical value mean arterial pressure is more than $65 \mathrm{mmHg}$ can improve mikrosirkulasi and autoreglasi brain, so that prevent the decline of awareness in patients with wounds of the head.
\end{abstract}

Keywords: mean artery pressure (MAP), consciousness injury head

\section{PENDAHULUAN}

Kecelakaan lalu lintas merupakan salah satu masalah kesehatan masyarakat yang dapat mempengaruhi semua sektor kehidupan dan salah satu penyebab utama trauma cranio cerebral. Dampak Trauma craniocerebral tersebut dapat mempengaruhi gangguan autoregulasi volume intrakranial yang terdiri dari otak, cairan serebrospinal dan darah dalam pembuluh darah. Perubahan salah satu volume tersebut tanpa diikuti respon kompensasi dari faktor yang lain menimbulkan tekanan intrakranial dan jumlah aliran darah dari sirkulasi sistemik yang diperlukan untuk memberi oksigen dan glukosa yang adekuat untuk metabolisme otak.

Salah satu hal yang sangat penting dalam asuhan keperawatan pada pasien dengan cidera kepala adalah menjaga kecukupan tekanan perfusi serebral. Jika jumlah aliran darah dari sirkulasi sistemik yang diperlukan untuk memberi oksigen dan glukosa yang adekuat 
untuk metabolisme di otak diatas $100 \mathrm{mmHg}$, maka potensial terjadi peningkatan tekanan intrakranial dan sebaliknya jika nilai tekanan perfusi serebral kurang dari $60 \mathrm{~mm} \mathrm{Hg}$, aliran darah ke otak tidak adekuat sehingga hipoksia, gangguan kesadaran dan kematian sel otak dapat terjadi. Sedangkan jika mean arterial pressure dan intrakranial pressure sama, berarti tidak ada tekanan perfusi serebral dan perfusi serebral berhenti (Black, J.M. \& MatassarinJacobs, 1993), sehingga tekanan perfusi otak dapat dijadikan sebagai prediktor keluaran tingkat defisit neurologis dan tigkat kesadaran. Laporan hasil penelitian sebelumnya yang dilakukan oleh Howard D. Sesso, Meir J. Stampfer, Bernard Rosner, Charles H. Hennekens, J. Michael Gaziano, JoAnn E. Manson (2000), menjelaskan bahwa tekanan sistole dan diastole, mean arterial pressure mampu memprediksi cardicasculer desease pada orang muda, sedangkan baik sistole atau rata-rata denyut nadi memprediksi cardicasculer desease pada orang dan memberikan saran apakah mean arterial pressure ada kaitannya korelasikan dengan tekanan sistole dan diastole lebih lebih baik.

Upaya yang dapat dilakukan untuk memprediksi adanya gangguan kesadaran akibat ketidakcukupan tekanan perfusi serebral yaitu dengan melakukan pengukuran lebih awal kecukupan tekanan rata-rata aliran darah ke otak. (Price, Sylvia A., \& Wilson, 2006) menjelaskan bahwa mekanisme autoregulator otak sangat berperan dalam mempertahankan aliran darah ke otak dalam rentang fisiologik $60 \mathrm{mmHg}-160 \mathrm{mmHg}$ tekanan arteri rata - rata dibawah kondisi tekanan darah arteri yang selalu berubah-ubah. Tekanan arteri rerata (mean artery pressure/MAP) merupakan mekanisme kompensasi dalam memepertahankan tekanan perfusi serebral yaitu dengan meningkatkan tekanan arteri rerata tersebut. Untuk itu, sangat penting menjaga kestabilan pasokan aliran darah otak agar tidak terjadi kerusakan lebih lanjut. Kecukupan rata-rata aliran darah ke otak merupakan bahan kajian yang penting dalam asuhan keperawatan pada pasien dengan cidera kepala. Kegagalan mengidentifikasi dan mengetahui tanda dan gejala tekanan perfusi otak dan kecukupan rerata arteri pasien dengan cidera kepala lebih awal merupakan resiko yang paling besar karena dapat menyebabkan kerusakan otak yang irreversibel sampai kematian.

\section{BAHAN DAN METODE}

Penelitian ini dilakukan untuk menjelaskan pengaruh dan prediksi kecukupan nilai kritis mean arteria pressure terhadap derajat kesadaran pada pasien cidera kepala menggunakan rancangan explanatory research dengan pendekatan cross sectional. Populasi pada penelitian ini adalah semua semua pasien yang mengalami yang mengalami cidera kepala yang dirawat di unit perawatan bedah Rumah Sakit PKU Muhammadiyah Delanggu Kabupaten Klaten yang berjumlah 34 sampel dengan pengambilan sampel menggunakan purposive sampling. Uji statistik yang digunakan untuk melihat sejauh mana pengaruh variabel nilai kritis mean arterial pressure dalam mendeteksi tingkat kesadaran menggunakan Uji Regresi dengan tingkat signifikansi yang dipahami $95 \%$.

\section{HASIL}

Sebaran jenis kelamin pasien cidera kepala dari 34 orang pada penelitian ini sebagian besar perempuan yaitu sebesar 18 orang (52.9\%) dan sisanya laki-laki sebesar 16 orang $(47.1 \%)$. Sebaran tingkat pendidikan pada pasien cidera kepala dari 34 orang yang diteliti sebagian besar SMA yaitu sebesar 13 orang $(38.3 \%)$, SD sebesar 12 orang (35.3\%), SMP sebesar 6 orang (17.6\%), dan sisanya perguruan tinggi sebesar 3 orang $(8.8 \%)$. Sebaran umur pada pasien cidera kepala dari 34 responden pada penelitian ini sebagian besar lanjut usia yaitu sebesar 20 orang (58.8\%), usia tua sebesar 13 orang (38.3\%), dan sisanya remaja sebesar 1 orang (2.9\%). Sebaran tekanan sistole pada pasien cidera kepala dari 34 orang yang diteliti sebagian besar dengan kategori normal dan pra hipertensi yaitu masing-masing sebesar 9 orang $(26.5 \%)$, hipertensi stadium I sebesar 6 orang (17.6\%), hipertensi stadium II sebesar 4 orang $(11.8 \%)$ dan sisanya dengan kategori rendah dan hipertensi parah yang masing-masing sebesar 3 orang (8.8\%). Sebaran tekanan sistole pada pasien cidera kepala dari 34 orang yang diteliti sebagian besar mempunyai tekanan diastole dengan kategori normal dan hipertensi stadium I yaitu masingmasing sebesar 10 orang (29.4\%), kategori rendah sebesar 6 orang (17.6\%), pra hipertensi sebesar 4 orang $(11.8 \%)$, hipertensi stadium II sebesar 3 orang $(8.8 \%)$ dan sisanya dengan kategori hipertensi parah sebesar 1 orang $(2.9 \%)$. Sebaran kecukupan mean artery 
pressure pada pasien cidera kepala dari 34 responden yang diteliti sebagian besar dengan kategori normal sebesar 20 orang (58.8\%), kategori tinggi sebesar 8 orang $(23.6 \%)$, dan sisanya dengan kategori kurang sebesar 6 orang (17.6\%). Sebaran tingkat kesadaran pada pasien cidera kepala dari 34 responden yang diteliti sebagian besar mempunyai tingkat kesadaran dengan kategori somnolen yaitu sebesar 13 orang (38.3\%), kategori koma dan apatis masing-masing sebesar 8 orang $(23.5 \%)$, dan sisanya dengan kategori komposmentis sebesar 6 orang $(14.7 \%)$.

Prediksi nilai rata-rata variabel kecukupan mean artery pressure terhadap tingkat kesadaran pada pasien cidera kepala pada penelitian ini menggunakan persamaan regresi yang digunakan adalah kesadaran $=10.552+1.012 \mathrm{x}+\mathbf{e}$.

Tabel 1. Rangkuman Hasil Analisis Regresi Linier Sederhana

\begin{tabular}{lccc}
\hline Variabel & $\begin{array}{c}\text { Koefisien } \\
\text { Regresi }\end{array}$ & $\begin{array}{c}\text { Hasil } \\
\text { Uji }\end{array}$ & Signifikansi \\
\hline $\begin{array}{l}\text { Koefisien } \\
\text { Regresi }\end{array}$ & 1.012 & $\mathrm{t}=7.648$ & 0.000 \\
$\mathrm{MAP}$ & & & \\
\hline Konstanta & 10.552 & $=1.157$ & 0.114 \\
\hline $\mathrm{R}$ & 0,870 & & \\
\hline $\mathrm{R}^{2}$ & 0,778 & & \\
\hline $\mathrm{F}$ & & $\mathrm{F}=38.717$ & 0.000 \\
\hline
\end{tabular}

Tabel 2. Nilai Prediksi Tingkat Kesadaran

\begin{tabular}{|c|c|c|c|c|}
\hline $\begin{array}{c}\text { Case } \\
\text { Number }\end{array}$ & $\begin{array}{c}\text { Std. } \\
\text { Residual }\end{array}$ & $\begin{array}{c}\text { Tingkat } \\
\text { Kesadaran }\end{array}$ & $\begin{array}{l}\text { Predicted } \\
\text { Value }\end{array}$ & Residual \\
\hline 1 & 1,565 & 4 & 2,43 & 1,568 \\
\hline 2 & $-1,687$ & 1 & 2,69 & $-1,691$ \\
\hline 3 &, 051 & 3 & 2,95 &, 051 \\
\hline 4 & $-1,687$ & 1 & 2,69 & $-1,691$ \\
\hline 5 & 1,049 & 4 & 2,95 & 1,051 \\
\hline 6 &, 567 & 3 & 2,43 & ,568 \\
\hline 7 &,- 689 & 2 & 2,69 &,- 691 \\
\hline 8 & 1,565 & 4 & 2,43 & 1,568 \\
\hline 9 & 1,049 & 4 & 2,95 & 1,051 \\
\hline 10 & ,309 & 3 & 2,69 & ,309 \\
\hline 11 & $-1,687$ & 1 & 2,69 & $-1,691$ \\
\hline 12 & , 051 & 3 & 2,95 &, 051 \\
\hline 13 &,- 689 & 2 & 2,69 &,- 691 \\
\hline 14 & ,309 & 3 & 2,69 & ,309 \\
\hline 15 &,- 431 & 2 & 2,43 &,- 432 \\
\hline 16 & 1,049 & 4 & 2,95 & 1,051 \\
\hline 17 &,- 689 & 2 & 2,69 &,- 691 \\
\hline 18 & 051 & 3 & 2,95 & 051 \\
\hline 19 & 1,049 & 4 & 2,95 & 1,051 \\
\hline 20 & $-1,687$ & 1 & 2,69 & $-1,691$ \\
\hline 21 & $-1,687$ & 1 & 2,69 & $-1,691$ \\
\hline 22 & ,309 & 3 & 2,69 & ,309 \\
\hline 23 &,- 689 & 2 & 2,69 &,- 691 \\
\hline 24 & , 051 & 3 & 2,95 & , 051 \\
\hline 25 & 309 & 3 & 2,69 & 309 \\
\hline 26 &,- 431 & 2 & 2,43 &,- 432 \\
\hline 27 & 1,307 & 4 & 2,69 & 1,309 \\
\hline 28 &,- 689 & 2 & 2,69 &,- 691 \\
\hline 29 &, 309 & 3 & 2,69 & ,309 \\
\hline 30 & 309 & 3 & 2,69 & 309 \\
\hline 31 & 309 & 3 & 2,69 & 309 \\
\hline 32 &,- 689 & 2 & 2,69 &,- 691 \\
\hline 33 & 1,565 & 4 & 2,43 & 1,568 \\
\hline 34 & ,309 & 3 & 2,69 & ,309 \\
\hline
\end{tabular}

Tabel 3. Rangkuman Hasil Uji t

\begin{tabular}{|c|c|c|c|}
\hline \multirow{2}{*}{ Variabel } & \multicolumn{2}{|c|}{ Harga $t$} & \multirow{2}{*}{ Keterangan } \\
\hline & t- Hitung & $\mathrm{t}-$ tabel & \\
\hline $\begin{array}{l}\mathrm{X}_{1} \mathrm{Y} \\
\alpha=0,05: N=34 \\
(\mathrm{df}) \mathrm{n}-\mathrm{k}-1\end{array}$ & 6.961 & 2.042 & $\begin{array}{c}\text { Ada } \\
\text { pengaruh }\end{array}$ \\
\hline
\end{tabular}

Berdasarkan tabel 1 dapat diperoleh perbandingan signifikansi uji $\mathrm{F}$ hitung sebesar $0.00<0.05$ artinya persamaan garis regresi yang telah digunakan mampu melakukan prediksi dengan baik (Nilai mean artery pressure (MAP) mampu memprediksi atau mendeteksi tingkat kesadaran pasien). Sedangkan koefisien regresi variabel mean artery pressure (X) sebesar 1.012, hal ini menunjukkan bahwa jika mean artery pressure mengalami kenaikan 1, maka tingkat kesadaran (Y) akan mengalami peningkatan sebesar 1.012. Hasil uji koefisien regresi pada peneltian ini diperoleh bernilai positif artinya terjadi hubungan yang positif antara mean artery pressure dengan tingkat kesadaran, yang artinya semakin nilai mean artery pressure meningkat maka semakin meningkatkan tingkat kesadaran.

Pada tabel 2, didapatkan nilai residual (unstandardized residual) pada penelitian ini diperoleh semakin mendekati nilai 0. Dengan demikian model regresi yang digunakan pada penelitian ini mampu melakukan prediksi dengan baik (nilai MAP mampu memprediksi atau mendeteksi tingkat kesadaran pasien). Nilai tingkat kesadaran yang diprediksi dapat dilihat pada kolom predicted value.

Hasil perhitungan uji $\mathrm{t}$ diperoleh derajat kebebasan (df) n-k-1=34-2-1=31 dengan pengujian 2 sisi (signifikansi $=0,025$ ), maka perbandingan harga $t_{\text {hitung }}=6.961>t_{\text {tabel }}=2.042$ dengan tingkat signifikansi 95\%. Dengan demikian Ho ditolak dan Ha diterima, artinya bahwa ada pengaruh secara signifikan antara nilai kritis mean artery pressure dengan tingkat kesadaran. Berdasarkan hasil uji statistik diperoleh nilai $\mathrm{R}$ square sebesar 0.778 , artinya nilai kritis mean artery pressure mempunyai pengaruh terhadap kesadaran pasien sebesar $77.8 \%$ dan sisanya dipengaruhi variabel lain. Rangkuman hasil uji t disajikan pada tabel 10.

Hasil uji statistik Uji $\mathrm{R}^{2}$ diperoleh nilai $\mathrm{R}$ square sebesar 0.778 , artinya nilai kritis mean artery pressure mempunyai kontribusi terhadap tingkat kesadaran pasien sebesar $77.8 \%$ dan sisanya sebesar $22.2 \%$ dipengaruhi variabel lain. 


\section{PEMBAHASAN}

\section{Karakteristik Pasien Cidera Kepala}

Sebaran data jenis kelamin cidera kepala dari 34 responden pada penelitian ini sebagian besar perempuan yaitu sebesar $52.9 \%$ dan sisanya laki-laki sebesar $47,1 \%$. Hal ini bertolak belakang dengan laporan penelitian Nurfaise., Moh. Zainuddin (2012) yang menjelaskan bahwa jenis kelamin laki-laki terdata sebagian besar mengalami cidera kepala, yaitu sebanyak 73,3\%, sedangkan perempuan adalah sebanyak $26,7 \%$. Namun demikian, dapat dijelaskan bahwa jenis kelamin perempuan pada penelitian terdata sebagian besar mengalami cidera kepala karena pelanggaran lalulintas dan kurangnya ketrampilan mengendarai sepeda motor sehingga mengakibatkan kecelekaan.

Sebaran umur pada pasien cidera kepala dari 34 responden pada penelitian ini sebagian besar adalah lanjut usia sebesar $58.8 \%$, usia tua sebesar $38.3 \%$, dan sisanya remaja sebesar 2.9\%. Di laporkan sebelumnya melalui penelitian yang dilakukan oleh Nurfaise., Moh. Zainuddin., Wicaksono (2012) yang menjelaskan bahwa kelompok usia pasien cedera kepala tersering adalah kelompok usia 15 - 60 tahun yaitu sebanyak $81,2 \%$. Kelompok usia pasien cedera kepala yang paling sedikit yaitu kelompok umur lebih dari 60 tahun sebesar $2 \%$, sedangkan untuk 5-14 tahun adalah sebanyak $(16,8 \%)$. Dengan melihat perbandingan data penelitian kejadian cidera kepala tersebut secara umum ada kesamaan angka kejadian cidera kepala, yang membedakan kategori kelompok umur. Pembagian kelompok umur ada penelitian ini adalah usia anak (2-17 tahun), remaja (18-21 tahun), subur (22-35 tahun), tua (36-45 tahun), dan usia lanjut $>45$ tahun). Usia lanjut pada penelitian merupakan prevalensi yang aling banyak hal ini terjadi disebakan usia tersebut merupakan risiko penurunan fungsi saraf, dan berkurangnya fungsi panca indera.

Tekanan darah dalam kehidupan seseorang bervariasi secara alami. Bayi dan anak-anak secara normal memiliki tekanan darah yang jauh lebih rendah daripada dewasa. Tekanan darah juga dipengaruhi oleh aktivitas fisik, dimana akan lebih tinggi pada saat melakukan aktivitas dan lebih rendah ketika beristirahat. Tekanan darah dalam satu hari juga berbeda; paling tinggi di waktu pagi hari dan paling rendah pada saat tidur malam hari. Kenaikan tekanan arteri pada usia tua biasanya dihubungkan dengan timbulnya arteriosklerosis. Pada penyakit ini, tekanan arteri yang terutama meningkat; pada kira-kira sepersepuluh dari semua orang tua akhirnya meinngkat di atas $200 \mathrm{mmHg}$. Tekanan darah seseorang dapat lebih atau kurang dari batasan normal. Jika melebihi nilai normal, orang tersebut menderita tekanan darah tinggi/hipertensi. Sebaliknya, jika kurang dari nilai normal, orang tersebut menderita tekanan darah rendah /hipotensi. Sejalan dengan bertambahnya usia, hampir setiap orang mengalami kenaikan tekanan darah. Tekanan sistolik terus meningkat sampai usia 80 tahun dan tekanan diastolik terus meningkat sampai usia 55 - 60 tahun, kemudian berkurang secara perlahan atau menurun drastis. Pada hipertensi sistolik terisolasi, tekanan sistolik mencapai $140 \mathrm{mmHg}$ atau lebih, tetapi tekanan diastolik kurang dari $90 \mathrm{mmHg}$ dan tekanan diastolik masih dalam keadaan normal. Hipertensi ini sering ditemukan pada usia lanjut. Hal ini sesuai pendapat yang disampaikan Potter, P.A \& Perry (2005) yang menjelaskan bahwa Tekanan darah dewasa cenderung meningkat seiring dengan pertambahan usia.

Perubahan tingkat kesadaran biasanya dimulai dengan adanya gangguan fungsi diensefalon yang ditandai kebuntuan, kebingungan, letargi dan akhirnya stupor. Penurunan kesadaran yang berkelanjutan terjadi pada disfungsi otak tengan dan ditandai dengan semakin dalamnya keadaan stupor. Akhirnya dapat terjadi disfungsi medula dan pons yang menyebabkan koma. Penurunan progresif kesadaran ini digambarkan sebagai perkembangan rostal-kaudal. Volume intrakranial yang kaku berisi jaringan otak (1400g), darah $(75 \mathrm{ml})$, dan cairan serebro spinalis $(75 \mathrm{ml})$, volume dan tekanan pada ketiga komponen ini selalu berhubungan dengan keadaan keseimbangan. Adanya peningkatan salah satu dari komponen ini menyebabkan perubahan pada volume yang lain. Keadaan patologis seperti lesi, epileptik, stroke, infeksi dan bedah intrakranial dapat mengubah hubungan antara volume intrakranial dan tekanan.sehingga dapat menyebab kan gangguan pada batang otak/diensefalon. Ketika terjadi gangguan kompensasi intracronial gagal dan terjadi peningkatan tekanan intrakranial (TIK). Peningkatan tekanan intrakranial secara singnifikan dapat menurunkan aliran darah dan menyebabkan iskemia. Bila terjadi iskemia komplet dan lebih dari 3 sampai 5 menit, otak akan menderita kerusakan yang tidak dapat di perbaiki. Hal ini terjadi di sebabkan oleh 
penurunan perfusi serebral yang mempengaruhi perubahan keadaan sel dan mengakibatkan hipoksia serebral. Pada fase-fase ini menunjukkan perubahan status mental dan tanda - tanda vital bradikardi, tekanan denyut nadi melebar dan perubahan pernafasan (Smeltzer, Suzanne C \& Bare, 2005).

\section{Prediksi tingkat kesadaran pasien dengan cidera kepala melalui pengukuran nilai kritis mean artery pressure}

Nilai mean artery pressure pada penelitian menjadi estimator secara tidak langsung terhadap tingkat kesadaran pada pasien cidera kepala. Kecukupan mean artery pressure di otak memberikan kontribusi berat ringannya gangguan kesadaran pada pasien cidera kepala. Hasil penelitian ini didukung laporan penelitian yang dipublikasikan oleh Jing-Yuan $\mathrm{Xu}, \mathrm{Si}$ Qing Ma, Chun Pan, Hong-Li He, Shi-Xia Cai, Shu-Ling $\mathrm{Hu}$, Ai-Ran Liu, Ling Liu, Ying-Zi Huang, Feng-Mei Guo (2015) yang menjelaskan bahwa peningkatan mean arterial pressure lebih dari $65 \mathrm{mmHg}$ dapat memperbaiki mikrosirkulasi pada pasien shock septic. Selain itu penelitian yang dilakukan oleh Marc Leone, Pierre Asfar, Peter Radermacher, Jean-Louis Vincent (2015) dijelaskan bahwa MAP sekitar 75 hingga $85 \mathrm{~mm} \mathrm{Hg}$ dapat mengurangi perkembangan cidera ginjal akut pada pasien hipertensi arteri kronis. Akan tetapi, hasil penelitian ini bertolak belakang dengan penelitian sebelumnya yang dilakukan oleh Balgis Desy, Joni Wahyuhadi, (2011) tentang hubungan antara tekanan intrakranial dan tekanan intraokular, tekanan intraokular dan mean arterial pressure pada pasien dengan cedera otak, dimana ditemukan korelasi yang signifikan antara tekanan intraokular pre dan pasca operasi juga tekanan intrakranial pre dan pasca operasi. Namun, korelasi antara tekanan intraokular dan tekanan intrakranial, dengan mean arterial pressure tidak signifikan.

Namun demikian, dapat dijelaskan bahwa pasien dengan ceidera kepala secara patofisiologi memungkinkan terjadinya kerusakan jaringan otak (cereberal) dan peningkatan tekanan intrakranial, sehingga sistem autoregulasi di otak sebagai susunan saraf pusat juga mengalami ganguan. Pada cidera kepala, terganggunya mekanisme autoregulasi otak akan berakibat aliran darah ke otak secara pasif tergantung pada mean arterial pressure, yang seanjutnya akan diikuti oleh turunnya tekanan perfusi otak (TPO) dan aliran darah ke otak (Guyton \& Hall, 2005).
Selain itu, menurut Hayens (2003) menjelaskan bahwa tekanan darah dikontrol oleh otak, sistem saraf otonom, ginjal beberapa kelenjar endokrin, arteri dan jantung. Otak merupakan pusat pengontrol tekanan darah di dalam tubuh. Serabut saraf adalah bagian sistem saraf otonom yang membawa isyarat dari bagian tubuh untuk menginformasikan kepada otak perihal tekanan darah, volume darah dan kebutuhan khusus semua organ. Semua informasi ini diproses oleh otak dan hasilnya dikirim melalui saraf menuju organ-organ tubuh termasuk pembuluh darah, yang ditandai dengan mengempis atau mengembangnya pembuluh darah. Sistem reflek neuronal ini yang mengatur mean arterial pressure bekerja dalam suatu rangkaian umpan balik negatif terdiri dari detektor, berupa baroreseptor yaitu suatu reseptor regang yang mampu mendeteksi peregangan dinding pembuluh darah oleh peningkatan tekanan darah, dan kemoreseptor, yaitu sensor yang mendeteksi perubahan PO2, $\mathrm{PCO} 2$ dan $\mathrm{PH}$ darah, neuronal aferen pusat kendali di medula oblongata. Neuronal eferen yang terdiri dari sistem saraf otonom serta efektor, yang terdiri dari alat pemacu dan selsel otot jantung, sel-sel otot polos di arteri, vena dan medula adrenal. Gangguan pada susunan saraf pusat dan tekanan intrakranial mengakibatkan penurunan aliran darah ke otak dan kerusakan otak yang selanjutnya mengakibatkan penurunan kesadaran.

\section{SIMPULAN DAN SARAN}

\section{Simpulan}

Hasil penelitian menunjukkan bahwa ada pengaruh yang positif nilai kritis mean artery pressure terhadap derajat kesadaran pasien cidera kepala dan nilai mean artery pressure mampu mendeteksi tingkat kesadaran pasien cidera kepala sebesar $77.8 \%$. Hambatan pelaksanaan penelitian ini adalah kesulitan mengetahui langsung riwayat dan teknik pertolongan awal yang dilakukan oleh masyarakat sebelum pasien tersebut dibawa di unit gawat darurat rumah sakit karena hal tersebut dapat mempengaruhi nilai mean artery pressure dan berat ringannya cidera kepala .

\section{Saran}

Penentu kebijakan (policy maker) hendaknya meningkatkan informasi tentang pertolongan pertama pada pasien cidera kepala 
bagi tenaga kesehatan khususnya teknik ambulasi pasien cidera kepala dan perlunya protap alogaritma atau prosedur tata urutan penanganan kegawatandaruratan pada pasien cidera kepala.

Perlunya memberdayakan kepada masyarakat untuk menjadi awam khusus yang diharapkan mampu memberikan penanganan kegawatandaruratan pasien cidera kepala dengan cara memberikan pendidikan dan pelatihan karena masyarakat sangat menentukan saat pertama kali menemukan korban.

\section{KEPUSTAKAAN}

Balgis Desy, Joni Wahyuhadi, M. (2011). Hubungan Antara Tekanan Intraokuli, Tekanan Intrakranial dan Mean Arterial Pressure Pada Penderita Cedera Otak Berat. Surabaya.

Black, J.M. \& Matassarin-Jacobs, F. (1993). Luckmann and Sorensen's MedicalSurgical Nursing: a psychophysiologic approach. (4, Ed.). Philadelphia: W.B. Saunders Company.

Guyton \& Hall. (2005). Buku Ajar Fisiologi Kedokteran. Jakarta: EGC.

Hayens, B. (2003). Buku Pintar Menaklukan Hipertensi. Jakarta: Ladang Pustaka dan Intimedia.

Howard D. Sesso, Meir J. Stampfer, Bernard Rosner, Charles H. Hennekens, J. Michael Gaziano, JoAnn E. Manson, R. J. G. (2000). Systolic and Diastolic Blood Pressure, Pulse Pressure, and Mean
Arterial Pressure as Predictors of Cardiovascular Disease Risk in Men. Hypertension AHA Journal, 36, 801-807.

Jing-Yuan Xu, Si-Qing Ma, Chun Pan, Hong-Li $\mathrm{He}$, Shi-Xia Cai, Shu-Ling Hu, Ai-Ran Liu, Ling Liu, Ying-Zi Huang, Feng-Mei Guo, Y. Y. and H.-B. Q. (2015). A high mean arterial pressure target is associated with improved microcirculation in septic shock patients with previous hypertension: a prospective open label study" yang hasilnya bahwa increasing mean arterial pressure from $65 \mathrm{mmHg}$ to normal levels is a. Critical Care Journal, 19(1), 130.

Marc Leone, Pierre Asfar, Peter Radermacher, Jean-Louis Vincent, and C. M. (2015). Optimizing mean arterial pressure in septic shock: a critical reappraisal of the literature. Critical Care Journal, 19(1), 101.

Nurfaise., Moh. Zainuddin., A. W. (2012). Hubungan Derajat Cedera Kepala Dan Gambaran Ct Scan Pada Penderita Cedera Kepala. Universitas Tanjungpura Pontianak.

Potter, P.A, Perry, A. . (2005). Buku Ajar Fundamental Keperawatan: Konsep, Proses, Dan Praktik (Edisi 4).

Price, Sylvia A., \& Wilson, L. . (2006). Pathofosiologi: Konsep Klinis ProsesProses Penyakit. Jakarta: EGC.

Smeltzer, Suzanne C \& Bare, B. G. (2005). Buku Ajar Keperawatan Medikal Bedah Brunner \& Suddarth. Jakarta: EGC. 